\title{
Penyuluhan Budaya Integritas ke Perangkat Desa di Desa Kerinjing Kecamatan Tanjung Raja, Kabupaten Ogan Ilir, Sumatera Selatan
}

\author{
Isni Andriana ${ }^{1 *}$, Lina Dameria Siregar ${ }^{1}$, dan Hera Febria Mavilinda ${ }^{1}$ \\ ${ }^{1}$ Fakultas Ekonomi, Universitas Sriwijaya, Sumatera Selatan, Indonesia \\ *Email korespondensi: isniandriana@fe.unsri.ac.id
}

Info Artikel: Diterima: 15 Agustus 2020; Disetujui: 17 September 2020; Dipublikasi: 16 Oktober 2020

\begin{abstract}
Abstrak: Kegiatan Pengabdian kepada masyarakat ini bertujuan untuk memberikan pengetahuan dan pemahaman kepada perangkat desa di desa kerinjing sehingga diharapkan hasil dari penyuluhan ini dapat diterapkan oleh para perangkat desa untuk mewujudkan pemerintahan desa yang berintegritas dalam menjalankan tugasnya menyelenggarakan pemerintahan desa, pelaksanaan pembangunan desa, pembinaan kemasyarakatan dan pemberdayaan masyarakat desa yang berintegritas.
\end{abstract}

Kata Kunci: Budaya Integritas, Perangkat Desa, Pembangunan Desa

\section{Kutipan:}

Andriana, I., Siregar, L.D., \& Mavilinda, H.F., (2020). Penyuluhan Budaya Integritas ke Perangkat Desa di Desa Kerinjing Kecamatan Tanjung Raja, Kabupaten Ogan Ilir Sumatera Selatan. Sricommerce: Journal of Sriwijaya Community Services, 1(2): 93-100. DOI: https://doi.org/10.29259/jscs.v1i2.17

\section{PENDAHULUAN}

\subsection{Latar Belakang}

Desa Kerinjing merupakan salah satu dari 241 desa yang ada diwilayah Kabupaten Ogan Ilir dan Salah satu dari 19 Desa di wilayah Kecamatan Tanjung Raja yang terletak tujuh Km ke arah Barat dari Ibu Kota Kecamatan dan 13 KM kearah Timur dari Ibu Kota Kabupaten dan mempunyai luas $\pm 3,00 \mathrm{KM} 2$, Desa Kerinjing terbagi menjadi dua dusun yang dipimpin oleh masing-masing Kepala Dusun.

Desa adalah suatu wilayah yang dihuni oleh sekelompok masyarakat yang saling mengenal, hidup bergotong-royong dan cenderung memiliki budaya yang relatif sama. Desa merupakan kesatuan masyarakat hukum yang dilegalkan melalui UU No.32 Tahun 2004 tentang Pemerintahan Daerah dan PP No.72 Tahun 2005 Tentang Desa. Pada tahun 2014 Pemerintah meresmikan UU No.6 Tahun 2014 tentang Desa sebagai revisi yang menggantikan peraturan tentang Desa yang tertuang dalam UU No.32 Tahun 2004 tentang Pemerintahan Daerah dan PP No.72 Tahun 2005 Tentang Desa, dan memberikan perubahan secara signifikan dalam tata kelola Pemerintahan Desa.

Dengan diberikannya wewenang yang semakin luas kepada Pemerintah Desa dalam mengurus rumah tangganya sendiri, desa pun mendapatkan kucuran dana dari Pemerintah Pusat berupa dana desa. Dana Desa adalah dana yang bersumber dari Anggaran Pendapatan dan Belanja Negara (APBN) yang diperuntukkan bagi desa yang ditransfer melalui Anggaran Pendapatan dan Belanja Daerah Kabupaten/Kota (APBD) yang bertujuan untuk membiayai penyelenggaraan pemerintahan, pelaksaan pembangunan, pembinaan kemasyarakatan dan pemberdayaan masyarakat desa. 


\subsection{Identifikasi dan Perumusan Masalah}

Berdasarkan UU No.6 Tahun 2014 tentang Desa,berdampak terhadap pemberian wewenang yang semakin luas kepada para perangkat Desa untuk mengurus rumah tangganya sendiri, sehingga diperlukan suatu organisasi perangkat desa yang berintegritas dalam menyelenggarakan pemerintahan desa yang akan membuat kemajuan terhadap desa tersebut. Untuk itu rumusan masalah dari pengabdian ini adalah untuk mengetahui Bagaimana budaya integritas di dalam organisasi pemerintahan desa di Desa Kerinjing.

\subsection{Tujuan dan Manfaat Kegiatan}

Berdasarkan rumusan masalah diatas, maka tujuan dan manfaat pengabdian ini adalah untuk mengidentifikasi budaya integritas didalam organisasi pemerintahan desa di Desa Kerinjing.

\section{STUDI PUSTAKA}

\subsection{Pengertian Perangkat Desa}

Pemerintah desa ditugaskan oleh pemerintah pusat untuk mengatur masyarakat pedesaan setempat berdasarkan dengan undang-undang yang ada demi mewujudkan pembangunan pemerintah diwilayah desa. Setiap desa dikepalai oleh seorang kepala desa yang dibantu oleh jajaran perangkat desa lainnya dalam mengurus setiap keperluan desa. Setiap jajaran memiliki fungsi dan tugasnya masing-masing. Berikut Struktur Pemerintahan Desa yang ada beserta tugas dan fungsinya:

1. Kepala Desa. Menurut UU RI No 6 Tahun 2014 Pasal 1 Ayat 3 kepala desa adalah pemerintahan desa atau yang disebut dengan nama lain yang dibantu perangkat desa sebagai unsur penyelenggara pemerintahan desa. Bertugas untuk menyelenggarakan pemerintah dan pemberdayaan desa.

2. Badan Pemerintahan Desa (BPD). Badan pemerintahan desa adalah lembaga yang anggotanya merupakan wakil dari penduduk desa yang ditetapkan secara demokratis berdasarkan kewilayahan. Fungsi dari BPD adalah membahas dan menyepakati rencana peraturan desa bersama kepala desa, menampung dan menyalurkan aspirasi dari masyarakat, dan mengawasi kinerja kepala desa.

3. Sekretaris Desa. Sekretaris desa adalah perangkat yang membantu kepala desa menjalankan tugasnya. Fungsi sekretaris meliputi menyiapkan dan melaksanakan pengelolaan administrasi desa, membantu persiapan penyusunan peraturan desa dan bahan untuk laporan penyelenggara pemerintah desa serta melaksanakan tugas lain yang diberikan kepala desa.

4. Pelaksana Teknis Desa. Terdiri dari: (1) Kepala Urusan Pemerintah (KAUR PEM) yang bertugas untuk membantu kepala desa dalam mengelola administrasi dan perumusan bahan kebijakan desa. Berfungsi melaksanakan kegiatan berkaitan dengan kependudukan, pertanahan, pembinaan ketentraman, dan ketertiban masyarakat. Kepala Urusan Pembangunan (KAUR PEMBANGUNAN) yang bertugas untuk membantu kepala desa dalam menyiapkan teknis pengembangan ekonomi desa serta mengelola administrasi pembangunan dan layanan masyarakat. Berfungsi untuk melaksanakan kegiatan administrasi pembangunan, menyiapkan analisa dan kajian perkembangan ekonomi masyarakat serta mengelola tugas pembantuan. (3) Kepala Urusan Kesejahteraan Rakyat (KAUR KESRA) yang bertugas membantu kepala desa mempersiapkan perumusan kebijakan teknis penyusunan program keagamaan dan melaksanakan program pemberdayaan dan sosial kemasyarakatan. Berfungsi melaksanakan hasil persiapan program keagamaan, pemberdayaan masyarakat dan sosial kemasyarakatan. (4) Kepala Urusan Keuangan (KAUR KEU). Berfungsi untuk membantu sekretaris desa mengelola sumber pendapatan, administrasi keuangan, penyusunan APB desa dan laporan keuangan desa. (5) Kepala Urusan Umum (KAUR UMUM). Fungsinya untuk membantu sekretaris dalam mengelola arsip desa, inventaris kekayan desa, dan administrasi umum. Dan juga sebagai penyedia, pemelihara dan perbaikan peralatan kantor. Serta pelaksana tugas lain yang diberikan oleh sekretaris desa. 
5. Pelaksana Kewilayahan. Terdiri dari: (1) Kepala Dusun. Kepala dusun atau kadus bertugas untuk membantu kepala desa melaksanakan tugasnya di wilayah dusun. Berfungsi membantu kinerja dan melaksanakan kegiatan yang diselenggarakan pemerintah desa di kawasan dusun dalam mensejahterakan masyarakat. (2) Administrasi Desa. Administrasi desa adalah kegiatan pencatatan data dan informasi penyelenggaraan pemerintah desa pada buku administrasi desa.

\subsection{Pengertian Budaya Integritas}

Integritas adalah suatu bentuk kejujuran yang diimplementasikan secara nyata dalam tindakan sehari-hari. Nilai integritas juga berkaitan dengan etika dan moral dimana setiap individu diwajibkan agar menaati standar teknis dan etika yang dimiliki oleh suatu organisasi (Arfah, Yuwaldi \& Mirza, 2018). Integritas merupakan kualitas yang melandasi kepercayaan public (Arman, 2018). Nilai-nilai integritas sangat penting untuk diterapkan dalam sebuah organisasi atau perusahaan, agar semua orang di dalamnya bisa saling percaya dan pada akhirnya bisa lebih cepat untuk mencapai tujuan bersama. Dalam hal ini sumber daya manusia yang berintegritas memiliki peranan penting dalam pencapaian tujuan Bersama (Falentina et all, 2018). Jika nilai-nilai integritas tidak dijalankan, maka kerjasama tim yang dilakukan akan menjadi lebih sulit akibat tidak terbangunnya kepercayaan yang komprehensif di antara mereka. Oleh karena itu pada hakekatnya orang yang berintegritas di dalam suatu organisasi tidak dapat terpisahkan dari aspek moral yang meliputi sisi baik dan buruk dari seorang manusia (Gunardi, 2017).

Kata 'integritas' dipakai secara luas untuk menyatakan kompaknya atau utuhnya sesuatu, teridentifikasi dari reaksinya terhadap rangsangan dari lingkungannya. Kata integritas berasal dari kata "Integrated" yang berarti bagian karakteristik dan keterampilan yang ada didalam diri suatu individu dan tercermin dari tindakan-tindakan individu tersebut (Atosokhi, 2014). Penyelisikan makna hakiki integritas pada akhirnya berujung pada pemahaman tentang pentingnya dua proses yang berlangsung serentak, yaitu proses pengendalian internal dan proses partisipasi eksternal. Pada kasus manusia atau institusi yang dikendalikan manusia, proses pengendalian internal berkaitan dengan persoalan bagaimana membangun dan mempertahankan identitas diri, sedangkan proses partisipasi eksternal berkenaan dengan persoalan bagaimana mewujudkan keputusan dan tindakan yang baik berdasarkan identitas diri itu.

Kata integritas umumnya dihubungkan dengan suatu keutamaan/kebajikan (virtue) atau karakter yang baik (Audi \& Murphy, 2006). Pengembangannya seringkali dikaitkan dengan upaya pencegahan korupsi, sehingga salah satu indikator yang paling sering disebutkan sebagai representasi sifat orang yang berintegritas adalah kejujuran. Namun, bagaimana menjelaskan kejujuran dalam kaitannya dengan kekompakan/keutuhan? Meskipun benar bahwa orang tidak mungkin memiliki integritas tanpa mempraktikkan kejujuran, tetapi bukan tidak mungkin seseorang yang selalu jujur memiliki tingkat integri tas yang rendah (Carter, 1996). Kejujuran buta tanpa pertimbangan kelayakan konteks malah bisa menunjukkan sifat narsistik dan ketidakpedulian terhadap akibat buruk yang bakal menimpa orang lain (Martin, 1996), suatu sifat yang tampaknya bertentangan dengan integritas.

Berbicara tentang integritas berarti berbicara tentang konsistensi antara dua hal, yaitu pikiran dan tindakan dalam bentuk pengambilan keputusan. Integritas sering dipahami dalam konteks perilaku dan perilaku integritas pada umumnya dipahami dalam kaitannya dengan etika dan moral (Yulianti, 2015). Seorang yang berintegritas memang tidak akan kompromistis ketika dihadapkan pada kesulitan, tetapi bukan tidak mungkin dia harus mengevaluasi dan memperbaiki komitmennya atas alasan fundamental agar dia tidak melawan dirinya sendiri (Davion, 1990). Indikator untuk mengukur integritas yaitu: dapat dipercaya, jujur, konsisten dalam memahami dan keinginan untuk menyesuaikan diri dengan nilai-nilai dan kebijakan organisasi serta mematuhi etika profesi dan bisnis (Haqq, 2016).

Integritas adalah dimana seorang pegawai diharuskan untuk bersikap jujur, berani, bijaksana dan bertanggung jawab (Wetik, 2018). Pendidikan merupakan strategi kebudayaan paling strategis dalam rangka membangun kualitas sumber daya manusia yang memiliki integritas sebagai pribadi maupun integritas sebagai warga negara (Santoso, 2015). Integritas dimaknai 
sebagai keselarasan antara hati, pikiran, perkataan, dan perbuatan yang baik dan benar. Indikator positif integritas ini dapat dilihat, yaitu; 1). Bertekad dan berkemauan untuk berbuat yang baik dan benar; 2). Berpikiran positif, arif, dan bijaksana dalam melaksanakan tugas dan fungsi; 3 ). Mematuhi peraturan perundang-undangan yang berlaku; dan 4). Menolak korupsi, suap, atau gratifikasi (Zainuri, 2016).

\section{METODE}

\subsection{Metode Pelaksanan Kegiatan Pengabdian}

Pelaksanaan kegiatan Pengabdian Pada Masyarakat ini dilakukan dengan menggunakan metode pembagian materi, ceramah, dan diskusi. Adapun sistematika pelaksanaan kegiatan pengabdian ini adalah sebagai berikut:

Tabel 1. Metode Pelaksanaan Kegiatan Pengabdian

\begin{tabular}{|c|c|c|c|c|}
\hline No & $\begin{array}{l}\text { Jenis } \\
\text { Kegiatan }\end{array}$ & $\begin{array}{l}\text { Partisipasi } \\
\text { Masyarakat }\end{array}$ & $\begin{array}{l}\text { Luaran } \\
\text { Kegiatan }\end{array}$ & Solusi Masalah \\
\hline 1 & $\begin{array}{l}\text { Penyuluhan budaya } \\
\text { integritas dan } \\
\text { pentingnya penerapan } \\
\text { budaya integritas dalam } \\
\text { kegiatan organisasi desa } \\
\text { untuk mewujudkan } \\
\text { pemerintahan desa } \\
\text { yang transparan, jujur } \\
\text { dan adil. }\end{array}$ & $\begin{array}{l}\text { Sebagai peserta } \\
\text { aktif dan } \\
\text { mepersiapkan } \\
\text { tempat selama } \\
\text { pelatihan } \\
\text { berlangsung }\end{array}$ & $\begin{array}{l}\text { Peserta memahami } \\
\text { nilai-nilai penting } \\
\text { dari penerapan } \\
\text { budaya integritas } \\
\text { dan mempunyai } \\
\text { komitmen untuk } \\
\text { menerapkan } \\
\text { budaya integritas } \\
\text { dalam menjalankan } \\
\text { organisasi desa }\end{array}$ & $\begin{array}{l}\text { Penyuluhan } \\
\text { budaya integritas } \\
\text { pada perangkat } \\
\text { desa diberikan } \\
\text { dengan } \\
\text { menyampaikan } \\
\text { materi-materi } \\
\text { dan contoh } \\
\text { implementasi } \\
\text { budaya integritas } \\
\text { yang ada di } \\
\text { organisasi desa }\end{array}$ \\
\hline 2 & Pelaksanaan Kegiatan & $\begin{array}{l}\text { Sebagai binaan dan } \\
\text { peserta }\end{array}$ & $\begin{array}{l}\text { Para peserta } \\
\text { penyuluhan } \\
\text { mempunyai } \\
\text { komitmen yang } \\
\text { tinggi untuk } \\
\text { menerapkan } \\
\text { budaya integritas } \\
\text { dalam menjalankan } \\
\text { organisasi desa }\end{array}$ & $\begin{array}{l}\text { Pemaparan } \\
\text { (presentasi) dan } \\
\text { penyuluhan } \\
\text { tentang budaya } \\
\text { integritas }\end{array}$ \\
\hline 3 & Evaluasi & $\begin{array}{l}\text { Menilai } \\
\text { pemahaman } \\
\text { peserta mengenai } \\
\text { budaya integritas }\end{array}$ & $\begin{array}{l}\text { Meninjau hasil } \\
\text { evaluasi }\end{array}$ & Penilaian evaluasi \\
\hline
\end{tabular}

\subsection{Waktu dan Rencana Jadwal Kegiatan} berikut:

Pengabdian ini dilaksanakan selama empat bulan dengan jadwal pelaksanaan sebagai 
Tabel 2. Waktu dan Rencana Jadwal Kegiatan

\begin{tabular}{llcccc}
\hline \multicolumn{1}{c}{ Kegiatan } & \multicolumn{4}{c}{ Bulan ke- } \\
No & 1 & 2 & 3 & $\mathbf{4}$ \\
\hline 1 & Mempersiapkan administrasi & $\mathrm{xx}$ & & & \\
2 & Mempersiapkan materi dan bahan & $\mathrm{xx}$ & & & \\
3 & Pelaksanaan kegiatan & & $\mathrm{xx}$ & & \\
4 & Evaluasi kegiatan & & & $\mathrm{xx}$ & \\
5 & Pengetikan laporan pengabdian & & & $\mathrm{xx}$ & \\
6 & Penyelesaian dan penjilidan laporan pengabdian & & & & $\mathrm{xx}$ \\
\hline
\end{tabular}

\section{HASIL DAN PEMBAHASAN}

\subsection{Acara Pembukaan}

Acara kegiatan penyuluhan budaya integritas kepada perangkat desa di Desa Kerinjing Kecamatan Tanjung Raja Kabupaten Ogan Ilir Sumatera Selatan dilaksanakan mulai pukul 08.00 WIB sampai dengan pukul 15.30 WIB. Kegiatan Penyuluhan budaya integritas ini dimulai dengan acara pembukaan berupa kata sambutan dari Kepala Desa Kerinjing dan Ketua Pelaksana kegiatan pengabdian dari Fakultas Ekonomi yang kemudian diakhiri dengan doa. Jumlah peserta yang mengikuti kegiatan penyuluhan budaya integritas sebanyak 30 (tiga puluh) orang yang terdiri dari 15 (lima belas) orang yang merupakan bagian dari perangkat desa dan 15 (lima belas) orang yang merupakan penduduk atau masyarakat desa di Desa Kerinjing. Adapun 15 (lima belas) orang yang bukan merupakan bagian dari perangkat desa tersebut disarankan untuk turut mengikuti kegiatan penyuluhan budaya integritas sebagai bentuk untuk mempersiapkan kaderisasi calon perangkat desa jika dikemudian hari terjadi pergantian perangkat desa sekaligus untuk menambah pengetahuan penduduk desa mengenai pentingnya budaya integritas dalam kegiatan organisasi desa.

\subsection{Acara Penyuluhan Budaya Integritas}

Acara penyuluhan ini dibuka oleh ketua pelaksana kegiatan pengabdian. Selanjutnya para dosen fakultas ekonomi yang menjadi panitia dalam kegiatan pengabdian ini membagikan meterimateri mengenai budaya integritas kepada para peserta penyuluhan. Memasuki acara inti yaitu penyuluhan mengenai budaya integritas yang disampaikan oleh tim dosen fakultas ekonomi yang merupakan panitia pelaksana dalam kegiatan pengabdian ini. Materi penyuluhan yang disampaikan kepada para peserta diantaranya mengenai:

1. Pentingnya penerapan budaya integritas dalam sebuah organisasi desa.

2. Pengertian budaya integritas dan kaitannya dengan etika dan moralitas.

3. Nilai-nilai integritas yang harus ada didalam sebuah organisasi desa.

4. Karakteristik pemimpin yang memiliki integritas.

5. Kaitan antara integritas dengan tindakan korupsi.

6. Tujuan dan manfaat dari penerapan budaya integritas di dalam organisasi desa.

\subsection{Evaluasi}

Dalam kegiatan penyuluhan budaya integritas ini, sebagian besar peserta khususnya yang menjadi bagian dari perangkat desa sangat antusias dalam mengikuti penyuluhan mengenai budaya integritas tersebut, karena budaya integritas dirasakan sangat cocok bagi perwujudan kepemimpinan perangkat desa dalam mencapai tujuan organisasi desa.

Setelah penyuluhan budaya integritas, para peserta khususnya yang menjadi perangkat desa di desa Kerinjing menyatakan komitmen mereka untuk mengimplementasikan nilai-nilai dari budaya integritas yang antara lain meliputi: transparansi atas prosedur dan pelaksanaan kerja 
organisasi desa, integritas dalam kata dan hati, perilaku konsisten, nilai kejujuran dan keadilan, bertanggung jawab, tidak membeda-bedakan, terpercaya, seimbang antara akuntabilitas dan kewenangan, mengetahui wewenang, peran, dan tanggung jawab, serta konsisten dalam stabilitas terhadap penerapan budaya integritas.

Di akhir acara, para dosen fakultas ekonomi yang menjadi panitia dalam kegiatan pengabdian ini membagikan angket atau kuisioner sebagai bahan evaluasi panitia untuk mengetahui respon dan manfaat yang dirasakan peserta serta kritik atau saran dari para peserta setelah mengikuti penyuluhan mengenai budaya integritas.

\subsection{Dokumentasi}

Berikut ini adalah rangkuman dokumentasi kegiatan di Desa Kerinjing, Kecamatan Tanjung Raja, Kabupaten Ogan Ilir, Sumatera Selatan:

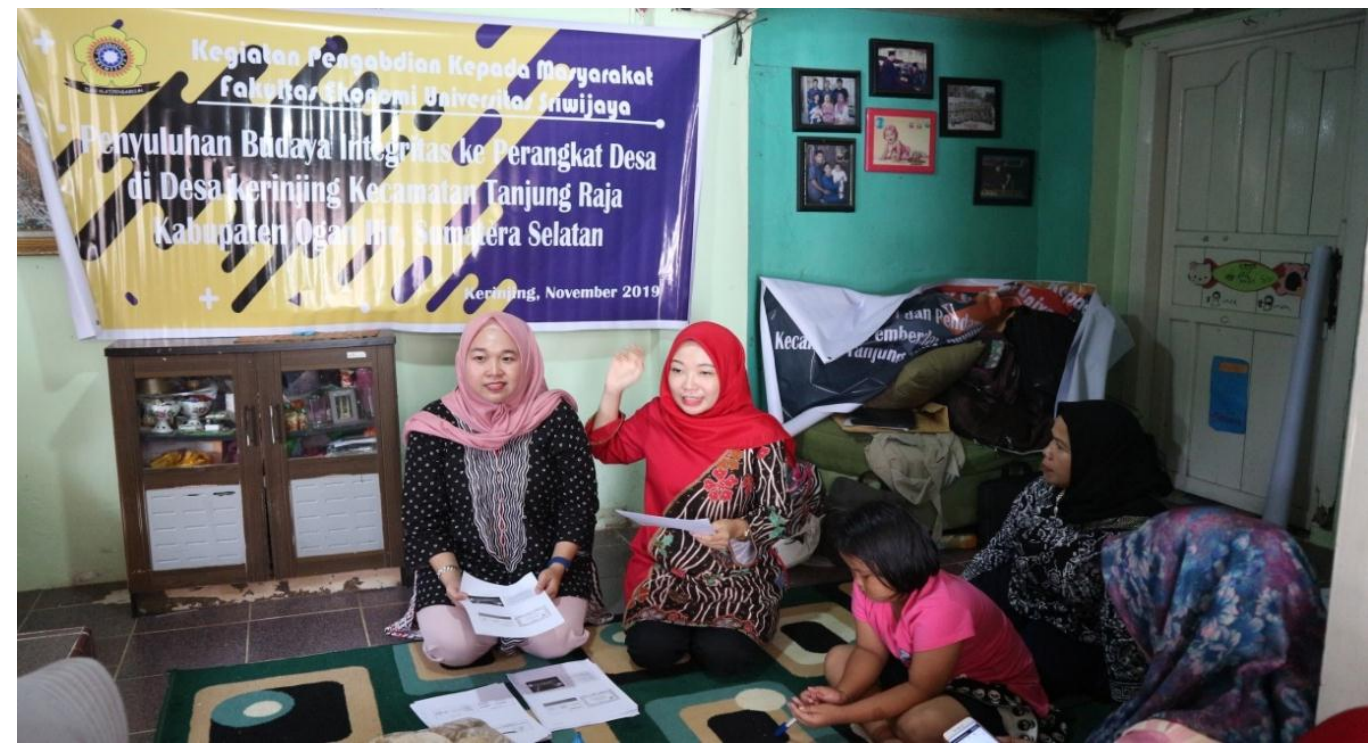

Gambar 1. Sesi Penuyuluhan Budaya Integritas

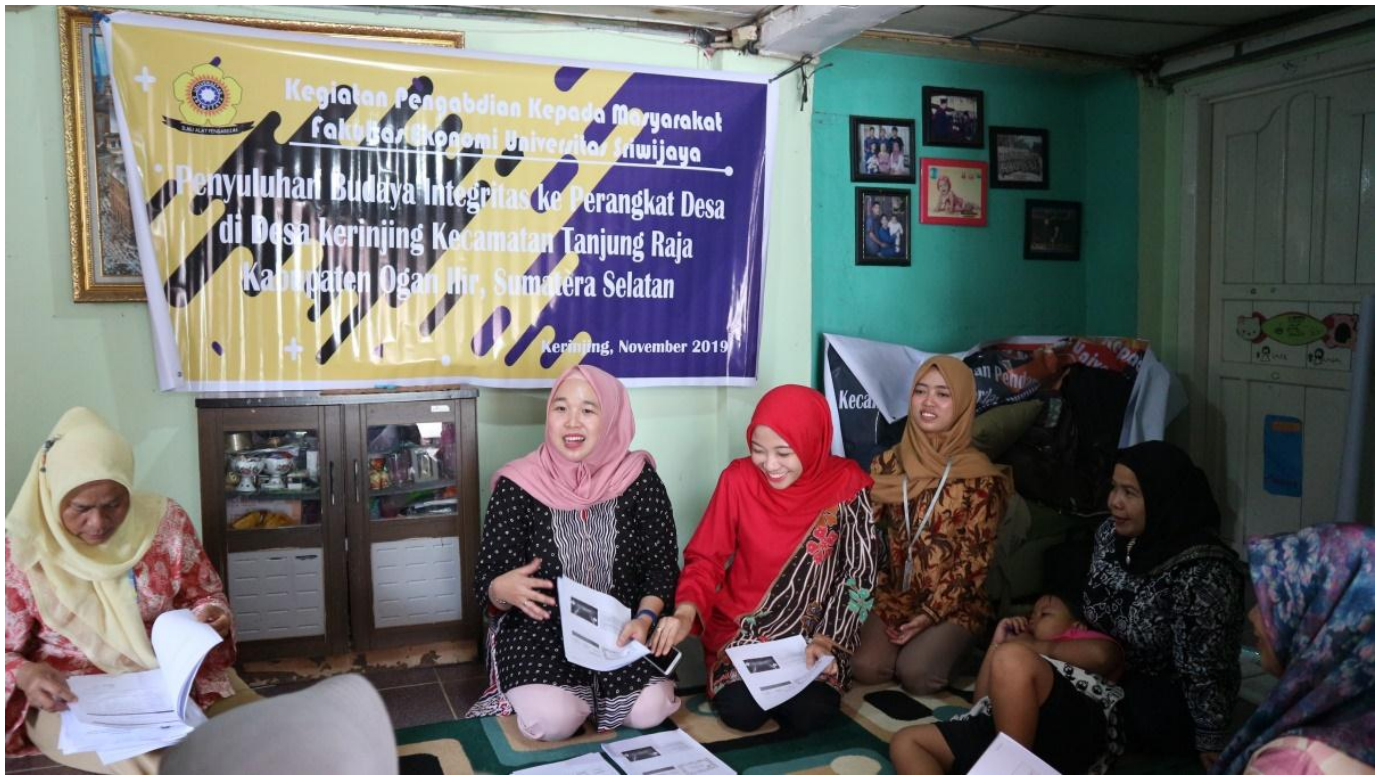

Gambar 2. Sesi Tanya Jawab Peserta 


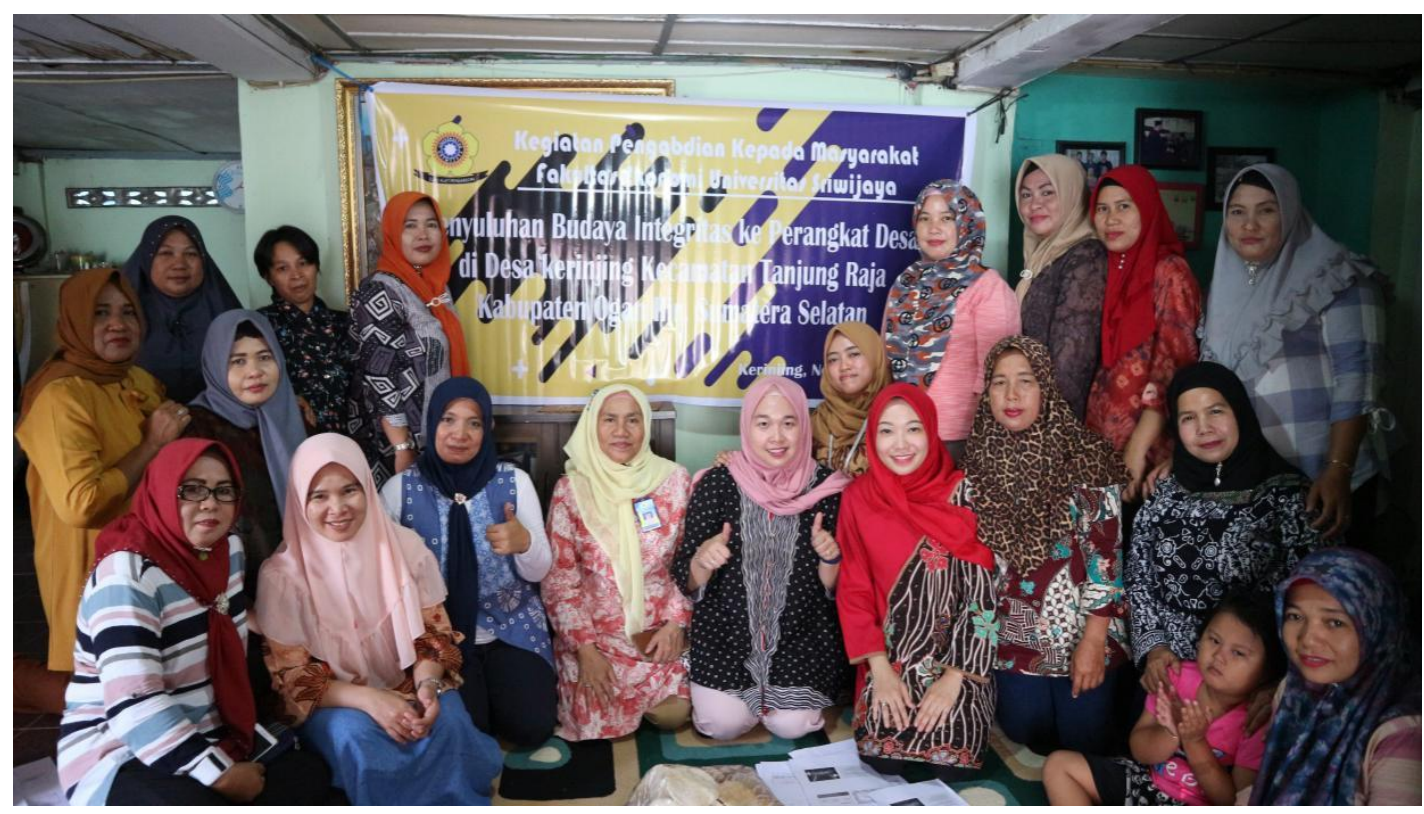

Gambar 3. Sesi Foto Bersama Peserta

\section{SIMPULAN}

Dari hasil pelaksanaan kegiatan di atas dapat disimpulkan bahwa integritas dibutuhkan oleh siapa saja, tidak hanya pemimpin namun juga yang dipimpin. Orang-orang menginginkan jaminan bahwa pemimpin mereka dapat dipercaya jika mereka harus menjadi pengikut-pengikutnya. Mereka merasa yakin bahwa pemimpin tersebut memperhatikan kepentingan setiap anggota tim dan pemimpin harus menaruh kepercayaan bahwa para anggota timnya melakukan tugas dan tanggung jawab mereka. Pemimpin dan yang dipimpin sama-sama ingin mengetahui bahwa mereka akan menepati janji-janjinya dan tidak pernah luntur dalam komitmennya. Perwujudan integritas bisa dilakukan dengan banyak cara, salah satunya dengan berperilaku jujur, bertanggung jawab dan dapat dipercaya serta konsisten.

Perangkat desa sebagai salah satu unsur pelaku desa memiliki peran penting tersendiri dalam mengembangkan kemajuan bangsa melalui desa. Perangkat desa yang berintegritas dapat terwujud dengan adanya masyarakat desa yang berintegritas pula. Penyuluhan budaya integritas ini dapat diterapkan oleh perangkat Desa Kerinjing sehingga terwujudlah pemerintahan desa yang berintegritas dalam menjalankan tugasnya menyelenggarakan pemerintahan desa, pelaksanaan pembangunan desa, pembinaan kemasyarakatan dan pemberdayaan masyarakat desa yang berintegritas.

Diharapkan dengan adanya kegiatan sosialisasi dan penyuluhan budaya integritas dapat memberikan pengetahuan dan menambah wawasan serta menciptakan komitmen yang kuat terhadap para perangkat desa mengenai pentingnya penerapan budaya integritas dalam menjalankan Organisasi Desa sehingga akan terwujud suatu sistem pemerintahan desa yang transparan, konsisten, taat aturan dan berorientasi terhadap kemajuan desa.

\section{UCAPAN TERIMA KASIH}

1. Fakultas Ekonomi Universitas Sriwijaya atas dana Pengabdian Kepada Masyarakat yang telah dianggarkan.

2. Kepala Desa desa Kerinjing Kecamatan Tanjung Raja Selatan, Kabupaten Ogan Ilir Provinsi Sumatera Selatan dan seluruh peserta kegiatan pengabdian kepada masyarakat.

\section{REFERENSI}

Atosokhi, A. (2014). Integritas Personal dan Kepemimpinan Etis. Jurnal Humaniora, 5(2), 950-959. 
Arman, S. (2018). Pengaruh Independensi, Integritas, Budaya Kerja, Kecerdasan Emosional dan Gaya Kepemimpinan terhadap Kinerja Auditor Kantor Akuntan Publik (Kap) di Makassar. Jurnal Ilmiah Akmen. 15(2): 278-293.

Audi, R., \& Murphy, P. (2006). The Many Faces of Integrity. Business Ethics Quarterly 16(1): 3-21.

Carter, S.L. (1996). Integrity. New York: Basic Books.

Davion, V.M. (1990). Integrity and radical change. Dalam Feminist Ethics, ed. Claudia Card. Kansas: Kansas University Press.

Endro, G. (2017). Menyelisik Makna Integritas dan Pertentangannya dengan Korupsi. Jurnal Integritas. 3(1). 132-152.

Falentina, K.G., Lambey, L., \& Pinatik, S. (2018). Pengaruh Integritas, Kompetensi, Dan Profesionalisme Terhadap Produktivitas Kerja. Jurnal Riset Akuntansi Going Concern. 13(3): 41-51.

Haqq, N. (2016). Pengaruh Budaya Organisasi terhadap Kinerja Karyawan melalui Motivasi sebagai Variabel Intervening Studi pada PT. Rahmat Jaya Perkasa Sidoarjo. Jurnal BISMA: Bisnis dan Manajemen. 9(1): 56-68.

Martin, M.W. (1996). Love's Virtue. Lawrence: University Press of Kansas.

Peraturan Pemerintah Republik Indonesia No. 72 Tahun 2005 Tentang Desa.

Salwa, A., Yuwaldi, A., \& Tabrani, M. (2018). Pengaruh Komitmen, Integritas Dan Kompetensi Terhadap Kinerja Pegawai. Jurnal Magister Manajemen Fakultas Ekonomi dan Bisnis Unsyiah, 2(1), 58-67.

Santoso, L. (2015). Model Strategi Kebudayaan dalam Pemberantasan Korupsi di Indonesia. Jurnal Review Politik, 5(1), 22-45.

Undang-undang Republik Indonesia No.32 Tahun 2004 tentang Pemerintahan Daerah.

Undang-undang Republik IndonesiaNo.6 Tahun 2014 tentang Desa.

Wetik, W. (2018). Analisis Pengaruh Komitmen dan Integritas terhadap Kinerja melalui Kompetensi Pegawai pada Kantor Kesyahbandaran dan Otoritas Pelabuhan Kota Manado. YUME: Journal of Management. 1(3), 137-151.

Yulianti, W. (2015). Pengaruh Kepemipinan Transformasional, Integritas Perilaku dan Kepercayaan terhadap Pimpinan Dalam Peningkatan Kinerja SDM. Jurnal Unissula, 2(1), 282-299.

Zainuri, A. (2016). Strategi Penerapan Lima Nilai Budaya Kerja di Kementerian Agama Menuju Pelayanan Prima. Jurnal Studi Islam. 14(1), 1-14. 